\title{
LEGAL PROTECTION FOR PARTIES THAT MAKE BINDING AGREEMENTS FOR THE SALE AND PURCHASE OF LAND THAT HAS NOT BEEN CERTIFIED IN THE RESOLVING LAND PARCELS PROCESS
}

\author{
Heriyanti \\ Universitas Prima Indonesia, Medan, Indonesia \\ heriyanti@unprimdn.ac.id
}

\begin{abstract}
Land purchase binding agreement in practice is often made in the form of an authentic deed before a Notary, so that the Deed of Sale and Purchase Agreement is an authentic act that has the strength of evidence is perfect. It is intended by the parties to further provide protection and legal certainty for the parties to make. Because notaries in making an act impartially and safeguard the interests of the parties objectively. With the help of the notary of the parties make binding sale and purchase agreement will get help in formulating the things that will be agreed upon. The method used in this research is normative juridical approach to literature. Legal protection of the fulfillment of the rights of the parties where one party is in default under the agreement binding sale and purchase is dependent upon the strength of the agreement binding sale and purchase is made, that if made by deed under the hands of the protection in accordance with the protection of the deed under the hand, whereas if it is made by or in the presence of a Notary, the account will automatically become a notary deed so that the protection is in accordance with the power of protection against authentic deeds.
\end{abstract}

\section{A. INTRODUCTION}

The problem of buying and selling land that has not been certified or are in the process of solving that is commonly found in people are buying and selling is not paid in full, the object of purchase is guaranteed or are being used as collateral, permit the transfer of rights has not been issued by the authorities, the taxes owed unpaid, the certificate has not "roya", as well as the certificate has not been broken (Still independent certificate). This problem would hamper the buyer to make the process behind the name. ${ }^{1}$

Solving plot must comply with the applicable spatial plan and its

1 Muchtar Rudianto, Perjanjian Pengikatan Jual-Beli Sebagai Perjanjian Pendahuluan, Penerbit Rajawali Press, Jakarta, 2010, p. 43 implementation should not lead to no provision of the legislation in force. Solving plot should not be detrimental to the interests of creditors who have security rights over the land. Therefore the soil solution should be done only after written consent was obtained from creditors or other authorized parties agree to eliminate the burden of another question. $^{2}$

Land purchase binding agreement in practice is often made in the form of an authentic deed before a Notary, so that the Deed of Sale and Purchase Agreement is an authentic act that has the strength of evidence is perfect. It is intended by the parties to give greater

2 Kitab Undang-undang Agraria dan Pertanahan, Publisher Fokusmedia, Bandung, 2009, p. 310 
protection and legal certainty to the parties who made it. Because notaries in making an act impartially and safeguard the interests of the parties objectively. With the help of the notary of the parties make binding sale and purchase agreement will get help in formulating the things that will be agreed upon.

Making the land purchase binding agreement that was born in the daily practice of course be allowed even if there are no settings in the Burgerlijk Wetboek $(B W)$. It is as a consequence of the principle of freedom contract adopted in our contract law is not contrary to the legislation, morality and order. Just as in the purchase agreement another where the agreement binding sale and purchase of land prospective seller is the need of people who can act freely on the land or in other words the prospective seller is the owner of land or a person authorized by the power to act on behalf of the owner of the land that became object binding sale and purchase agreement.

Transactions using binding sale and purchase agreement made under the hand notarized, but it can not be accompanied by the power of the Notary deed for the sale and purchase of objects not yet broken into the unit certificates and make it not so obvious.

The setting registration of splitting parcels of land under Article 48 of Government Regulation No. 24 of 1997 which determines that the request of the holder of the relevant right, a plot that is already registered can be broken down completely into several parts, the foreign individual is the unit of a new field with the status the same law with the original plot.3 In the implementation of all the land required to pay attention to solving

3 Mhd Yamin Lubis dan Abd Rahim Lubis, Hukum Pendaftaran Tanah, Publisher Mandar Maju, Bandung, 2012, p. 371 the minimum limit in accordance with the legislation in force.4 Technically solving the certificate provided for in Article 133 Permenag/Ka.BPN No.3/1997 on provisions for the implementation of Government Regulation No.24 of 1997.5 It is of course to avoid the occurrence of extensive areas of land into small violating minimum limit (fragmentation) so that the plots are no longer productive. 6

Implementation of the solution of plot carried out by the Land Office, Head of the Regional Office of the National Land Agency land that transferred the head office or its appointed Notary.7 Everyone has the right to recognition, security, protection and legal certainty and equal treatment before the law. The position and the position of a person before the law (the equality of law) is very important in order to realize the legal system and sense of justice. Everyone should have an equal opportunity to obtain legal protection through the legal process run by law enforcement. $^{8}$

The problem in this research is how the legal protection of the fulfillment of the rights and obligations

4 Florianus SP Sangsun, Tata Cara Mengurus Sertifikat Tanah, Publisher Visimedia, Jakarta, 2007, p. 68

5 NM. Wahyu Kuncoro, 97 Risiko Transaksi Jual Beli Properti, Publisher Raih Asa Sukses, Jakarta, 2015, p. 184

6 Mhd Yamin Lubis dan Abd Rahim Lubis, Op.Cit, p. 372

7 Kuniawan Ghazali, Cara Mudah Mengurus Sertifikat Tanah, Publisher Kata Pena, Jakarta, 2013, p. 86

8 Riza Firdaus, Perlindungan Hukum Bagi Pembeli Dalam Perjanjian Pengikatan Jual Beli Tanah Yang Masih Berstatus Hak Pengelolaan, Lambung Mangkurat Law Journal Vol 2 Issue 1, March (2017) 
of the parties where one party is in default in the deed of sale and purchase of land binding agreement made before a notary public, The method used juridical normative approach to literature.

\section{B. DISCUSSION}

\section{Rights and Obligations of the Parties When One Party Make Default In Deed Sale and Purchase of Land}

The position between the two sides, both the seller and prospective buyer is equitable and balanced. However, sometimes there is an imbalance if the position of one of the parties is stronger than the other party that influence the relationship achievement with one another, causing a balance disorder in an agreement, then in this case to the injured party is a reason to sue the invalidity of the agreement. ${ }^{9}$ If the agreement between the two sides has been reached it will give rise to rights and obligations between the parties.

In general, the rights of the sellers that accept the price he had sold from the buyer. ${ }^{10}$

1. Insist on the sale and purchase;

2. Submit object, wherein the object delivery is a transfer of objects that have been sold into the power and possession of the buyer;

3. The obligation to bear the buyer, the obligation of the seller to bear is that the control object is safe and secure and that if there

9 Herlien Budiono, Op.Cit, p. 318

10 Salim H.S, Op.Cit, p. 55 are defects in the object is hidden can be published reasons for the cancellation;

4. The obligation to bear against hidden defects, although the seller is not aware of any such defect, unless otherwise agreed;

5. The obligation to refund the purchase price received, if the seller knows the objects that have been sold are defective, and reimburse any expenses, losses, and interest to the purchaser;

6. If the object is sold destroyed due to hidden defects, the losses borne by the seller and are required to refund the purchase price and damages.

Buyers also have rights and obligations, the right for the buyer is to accept items that have bought both real and legally. As for the obligations of the buyer are:

1. Pay the purchase price of the object at a time and place that has been set (Article 1513 Civil Code);

2. Pay interest on the purchase price, if the object is sold and delivered results (revenues);

Binding sale and purchase agreement (PPJB) land ownership is a legal act which precedes the transition process of land ownership. PPJB is an agreement made by the seller and the buyer before the implementation purchase, this is because the elements that must be met for the sale and purchase. In terms of the PPJB land, problems that might arise as a result of unfulfilled elements of buying and selling that land certificates so 
because it is in the process of, or has not happened settlement payment to the land, or have not made a payment for taxes imposed on the sale the land purchase. In PPJB determined, the parties will make buying and selling has been bound and have the right and obligation to abide by the agreement. ${ }^{11}$ As an engagement, the contract of sale of land containing the rights and obligations of the parties that made it, so that if things had been agreed in the contract of sale are violated or not complied with by the party which made it can be said to have occurred in default.

The problem that often occurs in the deed of sale and purchase binding agreement is not fulfilled in a timely fashion buyer payments made to seller. agreement Sale and Purchase Agreement (PPJB) of the soil can be regarded as an agreement, where both parties mutually bind himself to trade, whether things that can not be met at the time of purchase binding agreement is carried out, usually involves price has not been paid off or land papers missing. Formulation of a period in the deed of the Sale and Purchase Agreement (PPJB) also deals with sanctions if binding agreements are violated by the parties. The both clause can provide legal certainty for the parties after facing Notary.

11 Dewi, R.P. and Purwadi. H. "Pembatalan Akta Perjanjian Pengikatan Jual Beli Akibat Wanprestasi (Studi Kasus Putusan No: 200/Pdt. G/2012/PN. Jkt. Sel)." Jurnal Repertorium 4.2 (2017).143-151, p. 143
If the period of fulfillment of their rights and obligations have been met, then the expiration of the agreement will also be automatically implemented. Therefore, the parties can feel safe and do not hesitate to be made a deed of the Sale and Purchase Agreement (PPJB) in the presence of a Notary. Besides the two clauses that should be practice there are also sanctions for violators of the agreement, in the deed of the Sale and Purchase Agreement (PPJB) are not clearly defined penalties for the parties when in default. For example, penalties are carried out by the seller to the buyer if the price paid by the buyer is not timely, and vice versa if the buyer agrees to a predetermined price and repayment is done by installments,

Actual deed of agreement Sale and Purchase Agreement (PPJB) is an authentic act that will not be disputed if one of the parties did not object or harmed, but the presence of some of the contents of the deed of agreement Sale and Purchase Agreement (PPJB) above, may arise dispute in question by one party. So according to the authors formulation period of fulfillment of rights and obligations under the deed becomes very important and must be detailed. Formulation period of time in the deed of the Sale and Purchase Agreement (PPJB) also deals with sanctions if binding agreements are violated by the parties. The both of clause can provide legal certainty for the parties after facing Notary.

According to Article 1234 of the Civil Code is an achievement is someone who betrays something, do 
something and not do something, otherwise considered to be in default if $a$ :

a. Do not do what is affordable will do.

b. Implement what he promised, but not as promised

c. Do what was promised but delayed

d. Doing something that should not be done according to the contract.

As a result of defaults that usually are liable for damages, cancellation of the contract, intermediate risk, and pay court costs. ${ }^{12}$ Default or known as the broken promises, the obligation of the debtor to fulfill a feat, if the obligations not affected because of the circumstances, the debtor is deemed to have did break a promise. ${ }^{13}$

In social life associated birth of a treaty should be maintained general principles of contract law enactment. Thus between the rights and obligations of the parties will be protected. If the rights and obligations are not properly enforced by either party, the conflicts of interest that are broken promises or tort. In case of breaking promises or tort necessary legal instruments to finish it even settlement agreement requires the judge's decision.14 Default is an event or situation, in which the debtor does not have obligations binding fine achievement, and the debtor has any element of it.15

Words of default derived from the Dutch which means poor performance.16 Default clause is an important thing to be included in agreement .R. Subekti decipher the meaning of the word default as follows: "If the debt (debtor) does not do what it promised to do, then it is said that he is in default. He is negligent or remiss or injuring the appointment. Or also she broke the covenant, that if he did or did something that should not be done. "17

The common understanding of default is a situation where the debt is not doing what it promised to do or violate the agreement in terms of the agreement that the Debtors should not be doing something, whereas he had done so ".18 Default as "the absence of an achievement", where achievement is meant here is an accomplishment in the Law of Treaties, which means as a matter that should be implemented as the content of an agreement. The term "lack of implementation of the promise" for default.19

Default is the omission of the debtor to meet its obligations in accordance with an agreed arrangement. To determine when a
12 Abdul R. Saliman, Op.Cit, p. 41

13 Agus Yudha Hernoko, Hukum Perjanjian Asas Proporsionalitas dalam Kontrak Jakarta: Prenada Media Group, 2010. P. 53

14 Yahman, Karakteristik Wanprestasi dan Tindak Pidana Penipuan, Jakarta : Penerbit Prestasi Pustaka Publisher, 2012, p. 50-77
15 J. Satrio, Wanprestasi Menurut KUHPerdata, Doktrin, dan Yurisprudensi, Bandung : PT Citra Aditya Bakti, 2012, p. 3

16 R. Subekti, Op.Cit, p. 45.

17 Ibid

18 Handri Raharjo, Op.Cit, p. 40

19 Wirjono Prodjodiko, Op.Cit, p. 38 
person should perform his duties can be seen from the agreement that has been made. In agreement is usually set when a person has to carry out its obligations, such as handing something or doing a deed. If the debtor does not do what he promised, he has been in default. A person is considered negligent or remiss or broken appointment or also violated the agreement if he did or did something that should not be done. $^{20}$

Achievement or in English is also called a "performance" in contract law is intended as an exercise of the things that are written in a contract by the parties have to remind myself to it, the implementation of which, in accordance with the "term" and "condition" as mentioned in the relevant contract. Meanwhile, with defaults (default or nonfulfilment, or mentioned with the term breach of contract) intended is not implemented properly achievements or obligations imposed by the contract against certain parties as contemplated in the relevant contract. 21

Legal protection to Land owners on the rights fulfillment of negligence or breach of contract

There is a possibility that really was one of the parties has been in default, remains partially achievement has been made or there is sufficient reason to suspend temporarily the implementation of existing achievements, or other reasons that led to the interests of any party in default should be protected. Therefore in the science of contract law is known as the principle of balance, the balance between the interests of the aggrieved party to the interests of the parties are in default. As has been explained that by law a contract is awarded to the terminal contract (with various consequences) the injured party by default action, but to maintain a balance, to parties that have then in default are also given rights or specific protection.

Associated with legal protection to the parties involved in an agreement, in advance of the legal protection itself consists of two syllables, namely protection means protecting action, while the law itself a rule in order to guarantee and safeguard the interests of all parties. Thus the legal protection of the acts that will provide protection to the rights of legal subjects in accordance with the applicable rules. There is some protection associated with defaults in the purchase agreement that include the following:

1. Protection against the seller that is a condition that is generally required by the seller itself, for example, is the seller who requested a certain period regarding payments to be made by the buyer that came with the proviso void if not filled.

2. Protection against the buyer. As with the seller, buyer protection is generally followed by an authorization can not be withdrawn again, with the intention that if the seller does not fulfill its obligations then the 
buyer can do the prosecution and will seek damages in accordance with the agreement. Buyers will usually ask for protection by requiring that the land concerned SHM held by a third party agreed upon. In addition to the authorization which can not be pulled so if buying and selling had been done, the buyer can make the switch right to the land without the presence of a previous seller. ${ }^{22}$

Referring to Article 1491 of the Civil Code, should the seller carry out transactions related to buying and selling beforehand have ensured that the objects are held securely without intervention of other parties, as well as the need to explain related important matters concerning the object so that there are no defects were hidden, in this act is referred to as preventive measures to prevent the things that would be detrimental to both sides. Then the next about the repressive legal protection in case of violation of the law, in this case the provision of law enforcement can be a fine, compensation, prison, and additional penalties and how that will be taken in the event of a dispute.

The provision of legal protection relating to the cancellation of the agreement binding sale and purchase of land titles in order for the parties to be able to restore the situation as it was before the

$22 \mathrm{Ni}$ LuhYunik Sri Antari, Pembatalan Perjanjian Pengikatan Jual Beli Hak Milik Atas Tanah, Acta Comitas Jurnal Hukum Kenotariatan, Vol. 03 No. 02, October 2018 agreement is made can be done by the sellers refund the payment made by the buyer, and the seller reacquire rights to land them.

Legal protection to parties who have been in default as follows:

1. Specific mechanisms for deciding Contract

In order for termination of the contract is not carried out at random even though the other party in default, then the law specify a particular mechanism in the event of termination of the contract. The mechanism is as follows:

a. Somasi implement obligations (Article 1238 Civil Code)

b. A reciprocal obligation to terminate the contract in court (Article 1266 Civil Code)

2. Restrictions on the Termination of Contract

As already explained that if one party has been in default, then the other party to the contract is entitled to terminate the contract in question. However, the right to terminate the contract by parties who have been harmed as a result of these defaults apply some restrictions juridical form:

a. Default must be serious

b. The right to terminate the contract has not been ruled out

c. Termination of the contract is not too late to do

d. Default accompanied by elements of the error 
For it will be reviewed one by one from the juridical restriction. Clauses relating to the time period and the sanctions contained in the deed of the Sale and Purchase Agreement (PPJB), the parties obtain legal certainty and the interests of the parties can also be protected by the state in the deed of the Sale and Purchase Agreement (PPJB). And the purpose of the parties make an authentic deed before Notary walk with certainty and assured predictability, another goal is for the parties to get protection and the parties are no longer worried about the situation that perform a treaty even though the format is only limited to the binding. If the parties still have any doubts about the deed of the Sale and Purchase Agreement (PPJB) were made, so prospective buyers can request to store their files on a third party that a notary. Storage of documents can be done by notaries until the signing of the Sale and Purchase Agreements (PPJB) have been carried out by the parties.

Legal protection in the deed of the Sale and Purchase Agreement (PPJB) can be defined by the prospective seller, usually a requirement that is usually requested by the prospective sellers themselves. For example, there are potential sellers in the Treaty Sale and Purchase Agreement (PPJB) had made request to the buyer in order to make a payment of money the buyer to a specific period which is accompanied by terms null and sanctions in case of late pay, others if the buyer does not meet the payment, as has been requested and agreed on the Sale and Purchase Agreement (PPJB) of land rights that have been made and agreed to be canceled and usually the seller will get money that has been paid unless the buyer requests an exception.

In contrast to the prospective seller protection, protection buyers are usually executed with requirements are also followed by an authorization request can not be withdrawn. The objective is when the seller does not fulfill the buyer can sue and ask for compensation in accordance with the agreements set out in the Sale and Purchase Agreement (PPJB).

Besides other protection is with the agreement to extend the power of which can not be withdrawn if all the requirements have been met to make a purchase, then the buyer can make an assignment to himself or to others even if the seller is not present in the signing of the Sale and Purchase Agreements (PPJB) it. Based on all the information above shows that the legal protection that can be given to all parties to the Sale and Purchase Agreement (PPJB). In addition to the legal protection of the deed of the Sale and Purchase Agreement (PPJB) is also based on Article 1338 of the Civil Code which is based on freedom of contract, as well as the goodwill of the parties to fulfill the agreement that has been made.

Legal protection of the fulfillment of the rights of the parties where one party is in default under the Agreement Sale and Purchase 
Agreement (PPJB) is dependent upon the strength of the Treaty Sale and Purchase Agreement (PPJB) are made, that if made by deed under the hands of the protective suit protection deed under the hand, while if made by or before a Notary is by itself aktanya be notarized deed so that the strength of protection in accordance with the protection of an authentic deed.

If the debtor is not in agreement because his mistake did not carry out his achievements and he is said to have been negligent or in default. Default means that do not meet a required like what has been stipulated in the agreement. Nonfulfillment of the obligation was caused by two things:

a. Due to an error debtors, either intentionally non-fulfillment of the obligations or through negligence.

b. Because circumstances force so beyond the ability of the debtor (debtor innocent).

Debtors who do not fulfill their obligations will be liable to pay damages, costs, interest to creditors, for the indemnity obligations to the debtor the Act specifies that the debtor first declared a state of neglect and the Act also provides provisions on what which can be included in the indemnification.

\section{Legal Protection Form Against Of The Sale And Purchase Binding Land Made Before A Notary When One Party In Default}

Legal protection of the parties where one party is in default under the agreement binding sale and purchase if the binding agreement is made by or before a notary is by itself the deed into a notarial deed so that the parties are protected throughout binding agreement of buying and selling is recognized by the parties, because agreement created by agreement of the parties, in accordance with the Consensualism principle and if there is one party that does not admit it, so the party participating in the deed must of proof to deny the formal aspects of the notarial deed, if not able to debunk, then the deed must be accepted by anyone.

Fulfillment of legal protection of the rights of the parties where one party is in default in a binding sale and purchase agreement, it depends on the position of the binding sale and purchase agreement and breach of contract. Default or broken promises or do not fulfill the engagement there are three kinds:

1. The debtor did not fulfill the engagement;

2. The debtor late for an engagement;

3. erroneous or inappropriate debtor fulfill engagements

Based on the information above shows that the broken promise can occur in several forms, as pointed out above. The same thing can happen in a binding sale and purchase agreement over land rights. Since it does not every person who makes a deal was able to implement all the agreements. That many notaries who believe themselves so often goes wrong in 
making the deed, such as not publishing a clause on penalties when the price of the object of purchase is paid by the buyer in several installments, which when the buyer is unable to pay the installments then there is no clause of the deed governing on fines.

The legal protection provided in the binding sale and purchase agreement is very strong because of the nature of evidence of binding sale and purchase agreement made before a public official in this case Notary has a very strong proof in accordance with the evidence of an authentic deed. Besides other protection afforded is legal protection that is based on the agreement made by the parties concerned with the agreement binding sale and purchase if we associate with the rules of the agreement, provided for in Article 1338 Book of the Law of Civil Law, which reads: all approvals are made legally valid as law for those who make it.

In addition there are some protections can be provided if one of the parties in default in a binding sale and purchase agreement:

1. Protection against the prospective seller

Legal protection can be given to the prospective seller usually is in the form of requirement that is usually requested by the prospective sellers themselves. For example, there are a few potential sellers in the agreement binding sale and purchase made request to the buyer in order to make a payment of money the buyer to a specific period which is accompanied by terms void, for example, if the buyer does not meet the payment, as has been requested and agreed the treaty binding sale and purchase rights on land that has been made and agreed to be canceled and the seller usually will not returns the money has been paid unless the buyer requests an exception.

It is, as has happened between Mr. Husin (a landowner in Central Jakarta) with Mr. Hasan (buyer/Private employees in West Jakarta). After the two agreed to conduct the sale and purchase of a land plot and a house on it, but Mr. Hasan has not been able to pay all at once and the two agreed to hold a preliminary binding is binding sale and purchase. In a binding sale and purchase Mr. Husin as landowners ask repayment for sure and if not done in accordance with the time the purchase agreement becomes null and void and the money that has been paid will not be requested again as a form of compensation and it was agreed by Mr Hasan ,

In practice it turned out after making an advance payment of Rpx, Mr. Hasan did not commit any further payments in accordance with the agreed in the binding sale and purchase, and after remind you to meet Mr. Hasan has not met also the party of Mr. Husin then cancel the agreement binding sale and 
purchase it and the money was not returned.

2. Protection against the prospective buyer

In contrast to the protection of the protection seller to the buyer usually executed with requirements are also followed by an authorization request can not be withdrawn. The objective is when the seller does not fulfill the buyer can sue and and ask for compensation in accordance with the agreements stipulated in the binding sale and purchase agreement.

Terms are usually requested by the purchaser for its protection is to request that the certificate or the mark of property rights over the land held by the third party is usually a Notary Public or other person designated and agreed upon by the seller and the buyer Besides other protection is by agreement granting authorization which can not be withdrawn if all the requirements have been met to make a purchase, then the party may transfer rights pemebeli although the seller did not attend the signing of the deed of sale purchasing.

Based on all the information above shows that legal protection can be given to the fulfillment of the rights of all parties in a binding sale and purchase in addition to appropriate legal protection provided by the power of the authentic act can also be based on Article 1338 Book of the Law of Civil Law, as well as the goodwill of the parties to fulfill the agreement that has been made.

\section{CONCLUSION}

$V$ ffLegal protection against the fulfillment of the rights of the parties if one party defaults on the sale and purchase agreement is very dependent on the strength of the sale and purchase binding agreement, if it is made under a deed then the protection is in accordance with the protection under the hand, whereas if it is made by or in the presence of a Notary, then the act itself becomes a notary deed so that the strength of the protection is in accordance with the protection of the authentic deed. 


\section{BIBLIOGRAPHY}

Agus Yudha Hernoko, Hukum Perjanjian Asas Proporsionalitas dalam Kontrak Komersial, Jakarta : Prenada Media Group, 2010, p. 53

Dewi, R.P. and Purwadi. H. "Pembatalan Akta Perjanjian Pengikatan Jual Beli Akibat Wanprestasi (Studi Kasus Putusan Nomor: 200/Pdt. G/2012/PN. Jkt. Sel)." Jurnal Repertorium 4.2 (2017).143-151, p. 143

Florianus SP Sangsun, Tata Cara Mengurus Sertifikat Tanah, Visimedia Publisher, Jakarta, 2007, p. 68

J. Satrio, Wanprestasi Menurut KUHPerdata, Doktrin, dan Yurisprudensi, Bandung : PT Citra Aditya Bakti, 2012, p. 3

Kuniawan Ghazali, Cara Mudah Mengurus Sertifikat Tanah, Kata Pena Publisher, Jakarta, 2013, p. 86

Muchtar Rudianto, Perjanjian Pengikatan Jual-Beli Sebagai Perjanjian Pendahuluan, Rajawali Press Publisher, Jakarta, 2010, p. 43

Mhd Yamin Lubis dan Abd Rahim Lubis, Hukum Pendaftaran Tanah, Mandar Maju Publisher, Bandung, 2012, p. 371

NM. Wahyu Kuncoro, 97 Risiko Transaksi Jual Beli Properti, Raih Asa Sukses Publisher, Jakarta, 2015, p. 184

Ni Luh Yunik Sri Antari, Pembatalan Perjanjian Pengikatan Jual Beli Hak Milik Atas Tanah, Acta Comitas Jurnal Hukum Kenotariatan, Vol. 03 No. 02 October 2018

Riza Firdaus, Perlindungan Hukum Bagi Pembeli Dalam Perjanjian Pengikatan Jual Beli Tanah Yang Masih Berstatus Hak Pengelolaan, Lambung Mangkurat Law Journal Vol 2 Issue 1, March (2017)

Yahman, Karakteristik Wanprestasi dan Tindak Pidana Penipuan, Jakarta : Prestasi Pustaka Publisher, 2012, p. 50-77 